\title{
A Sinorhizobium meliloti minE mutant has an altered morphology and exhibits defects in legume symbiosis
}

\author{
Jiujun Cheng, Christopher D. Sibley, Rahat Zaheer and Turlough M. Finan
}

Correspondence

Turlough M. Finan

finan@mcmaster.ca

Received 16 August 2006

Revised 11 October 2006

Accepted 12 October 2006
Center for Environmental Genomics, Department of Biology, McMaster University, Hamilton, Ontario L8S 4K1, Canada

\begin{abstract}
Sinorhizobium meliloti differentiates from rod-shaped, free-living cells into pleomorphic, non-dividing, $\mathrm{N}_{2}$-fixing bacteroids within alfalfa root nodules. Here, the role of the $\min C D E$ genes in bacteroid differentiation and in free-living cell division is examined. Disruption of the minE gene resulted in large, swollen and branched free-living cells, and in symbiosis a minE mutation resulted in a defect in nitrogen fixation with activity reduced by approximately $70 \%$ compared to the wild-type. It has been demonstrated that the $\min C D E$ genes form an operon driven by a promoter located $173 \mathrm{bp}$ upstream of $\min C$. The $\min C D E$ genes were expressed in free-living cells and in both the infection zone and the symbiotic zone of alfalfa nodules; however, no changes in the free-living cell morphology, growth or symbiotic $\mathrm{N}_{2}$ fixation were detected as a result of deletion of these genes. Induced production of individual or combinations of Min proteins in S. meliloti altered its rod-shaped cell morphology. Moreover, cell morphologies resulting from the overexpression of the S. meliloti Min proteins in Escherichia coli suggested similar functions for the E. coli and $S$. meliloti min genes. These data suggest that there is greater redundancy in the roles of cell division genes in S. meliloti compared with E. coli.
\end{abstract}

\section{INTRODUCTION}

Division of a bacterial cell normally occurs at the midcell, and hence requires the cell to locate and position cell division machinery at this midcell site (Errington et al., 2003). The first known step in the formation of the prokaryotic division machinery is the polymerization of the cytosolic tubulin homologue FtsZ into a ring-like structure (Z-ring) encircling the dividing cell at the position of a potential septum (Bi \& Lutkenhaus, 1991). Proper localization of the Z-ring is determined by at least two proposed mechanisms: nucleoid occlusion and the Min system (Errington et al., 2003). The nucleoid occlusion model states that all sites along the length of the cell are potential division sites competent for cell division; however, division is inhibited at positions occupied by nucleoids. Therefore, upon nucleoid segregation the midpoint becomes available for the placement of an FtsZ ring and the central division site.

In Escherichia coli the MinCDE proteins act together as a negative regulatory element, restricting the formation of septa at polar division sites, ensuring that the FtsZ ring is placed correctly at the midcell (Errington et al., 2003). MinC acts as an inhibitor of septation and is given topological specificity by the action of MinE, whereas MinD is required

Abbreviation: ESEM, environmental scanning electron microscopy. for the recruitment of MinC and MinE to the cytoplasmic membrane (Hale et al., 2001). The MinCD proteins form a MinE-dependent spiral complex that oscillates from pole to pole and inhibits the formation of the Z-ring at polar locations while allowing proper localization of the Z-ring at the midcell (Hale et al., 2001; Shih et al., 2003).

The Min system is found in a diverse range of bacteria (Errington et al., 2003). The Gram-positive organism Bacillus subtilis contains homologues to both MinC and MinD, but lacks a MinE counterpart (Cha \& Stewart, 1997; Edwards \& Errington, 1997). The MinC and MinD proteins do not oscillate from pole to pole and midcell selection is controlled by a protein, DivIVA, which lacks significant amino acid sequence similarity to MinE. The DivIVA protein stably associates with the B. subtilis cell poles and retains $\mathrm{MinCD}$ at the poles, thereby preventing division at those sites (Cha \& Stewart, 1997; Edwards \& Errington, 1997; Marston \& Errington, 1999). Additionally, MinCDE homologues have been characterized in coccal Neisseria gonorrhoeae (Ramirez-Arcos et al., 2001; Szeto et al., 2001) and the spherical-celled cyanobacterium Synechocystis (Mazouni et al., 2004).

Sinorhizobium meliloti is a Gram-negative, rod-shaped alphaproteobacterium that induces $\mathrm{N}_{2}$-fixing root nodules on the legume alfalfa (Medicago sativa). The genome of this micro-organism consists of three replicons: a circular 
chromosome $(3.7 \mathrm{Mb})$ and two megaplasmids pSymA (1.3 Mb) and pSymB (1.7 Mb) (Galibert et al., 2001). The $S$. meliloti genome sequence reveals a single copy of minCDE gene homologues on the $\mathrm{pSymB}$ megaplasmid (Finan et al., 2001; Galibert et al., 2001). During nodule formation, S. meliloti cells invade the host plant through root hairs and enter the plant cells where they differentiate from 1-2 $\mu \mathrm{m}$ long small rods into enlarged filaments and branched cells 5-10 $\mu \mathrm{m}$ in length (Mergaert et al., 2006; Paau et al., 1977). In a recent study Mergaert et al. (2006) examined the viability of $S$. meliloti differentiated bacteroids and concluded that they are non-dividing. They also reported that the genome content of the bacteroids is $24 \mathrm{C}$ ( $\mathrm{C}$ being the haploid DNA content), while the content in free-living bacteria was $1-2 \mathrm{C}$. The genes and factors involved in and controlling the morphological and genome content changes during bacteroid differentiation have not been well characterized. Here we report on experiments designed to investigate the requirement of $\min$ genes for cell division and symbiotic $\mathrm{N}_{2}$ fixation in $S$. meliloti. We have constructed various min mutants and min reporter gene fusions, and overexpressed the min genes in S. meliloti and $E$. coli. Our findings demonstrate that while minDE genes are expressed in free-living cells and within nodules, they are not absolutely required for cell division and symbiotic $\mathrm{N}_{2}$ fixation.

\section{METHODS}

Bacterial strains, plasmids, media and growth conditions. The strains and plasmids used in this work are listed in Table 1. The E. coli cultures were grown at $37^{\circ} \mathrm{C}$ in Luria broth (LB), and S. meliloti strains were grown at $30^{\circ} \mathrm{C}$ in $\mathrm{LB}$ containing $2.5 \mathrm{mM} \mathrm{CaCl}_{2}$ and $2.5 \mathrm{mM} \mathrm{MgSO}_{4}$ (LBmc). Defined M9 medium contained M9 salts (Miller, 1972) supplemented with $0.25 \mathrm{mM} \mathrm{CaCl}_{2}, 1 \mathrm{mM} \mathrm{MgSO}$, $0.3 \mu \mathrm{g}$ biotin $\mathrm{ml}^{-1}, 5 \mathrm{ng} \mathrm{CoCl} \mathrm{ml}^{-1}$ (Watson et al., 2001) and $15 \mathrm{mM}$ succinate or glucose. When necessary, antibiotics were used as described previously (Finan et al., 1986). For Min protein overexpression and electron microscopy, E. coli strains were grown to an $\mathrm{OD}_{600}$ of 0.1 and the growth continued for $4 \mathrm{~h}$ after IPTG was added to a final concentration of $0.1 \mathrm{mM}$. S. meliloti cultures were grown to an $\mathrm{OD}_{600}$ of 0.1 and then induced with IPTG $(1 \mathrm{mM})$ for $16 \mathrm{~h}$.

DNA manipulations and genetic techniques. Standard methods were used for DNA isolation, digestion, agarose gel electrophoresis, DNA ligation and transformation (Sambrook \& Russell, 2001). Synthesis of oligonucleotides (Table 2) and sequencing of PCR products were performed at MOBIXLab (McMaster University, Hamilton, Ontario, Canada). Bacterial matings were done as described previously (Finan et al., 1986).

To delete and replace the entire minCDE genes with the $\Omega$ Sp cassette from pHP $45 \Omega$ (Prentki \& Krisch, 1984), the $\Omega$ Sp cassette was cloned between the 844 and 911 bp PCR-amplified DNA fragments (primer pairs AB32663/AB32664 \& AB32661/AB32662, respectively) flanking the outside of $\min C$ and $\min E$, serially cloned into pJQ200-mp18 (Quandt \& Hynes, 1993). The resultant plasmid, pTH1426 (Fig. 1a), was transferred into S. meliloti wild-type strain Rm1021 and a single crossover recombinant was selected on an LB plate containing $\left(\mu \mathrm{g} \mathrm{ml}^{-1}\right)$ streptomycin, (200), gentamicin (60) and spectionmycin
(200). The double crossover integrant SmK850 was obtained by plating the transconjugants on LB agar with $5 \%$ sucrose and screening the colonies for gentamicin sensitivity and spectinomycin resistance.

To disrupt the $\min C$ gene, a 570 bp DNA fragment internal to minC was PCR-amplified using AB31700 and AB31698 primers, and cloned downstream of the trp terminator and upstream of $g u s A$ in a suicide vector, pVO155 (Oke \& Long, 1999), to obtain plasmid pTH1218 (Fig. 1a). Integration of pTH1218 by homologous recombination into the $S$. meliloti genome resulted in a $\min C$ and $g u s A$ gene fusion, and promoterless $\min C^{\prime} D E$ genes in SmK690 (Fig. 1b).

To make a polar $\min D$ mutation (i.e. $\min C^{+} D^{-} E^{-}$) a 773 bp DNA fragment carrying $\min C$ (without its translational start codon) was obtained by PCR using primers AB31700/AB31697 and cloned upstream of gusA and downstream of the trp terminator in pVO155 to yield pTH1219 (Fig. 1a). Homologous recombination of pTH1219 into $S$. meliloti genomic DNA produced a functional copy of minC and disrupted the minCDE operon in SmK691 (Fig. 1b). To disrupt the minE gene, a 1657 bp DNA fragment carrying the $\min C D$ gene region was PCR-amplified using primers AB31700/AB31699 and cloned downstream of the trp terminator and upstream of gusA in pVO155 to obtain pTH1220 (Fig. 1a). Strain SmK692, resulting from integration of pTH1220 into the S. meliloti genome, contained functional minC and $\min D$ genes with a gus $A$ gene fusion at the $3^{\prime}$ end of $\min D$ (Fig. 1b).

To overexpress S. meliloti min genes in both E. coli and S. meliloti, a broad-host-range expression vector, pTH1227, was constructed. A 1510 bp DNA fragment carrying the $l a c I^{9}-P_{\text {tac }}$ cassette from pMAL-c2x (New England Biolabs) was PCR-amplified using primers AB32193/ AB32194 and inserted upstream of gusA in a broad-host-range plasmid, pFUS1 (Reeve et al., 1999), to obtain pTH1227. Overexpression of the gusA gene after induction with IPTG was determined by measuring GusA activities in E. coli M65 and S. meliloti SmK700, both of which contained the vector pTH1227. DNA fragments carrying min genes with a modified ribosome-biding site were PCR-amplified using primers AB31697/AB32186 (807 bp) for $\min C, \mathrm{AB} 31699 / \mathrm{AB} 32187$ (850 bp) for $\min D$, AB32188/AB31979 (336 bp) for minE, AB31699/AB32186 (1694 bp) for minCD, AB32186/AB31979 (1995 bp) for $\operatorname{minCDE}$ and AB32187/AB31979 $(1151 \mathrm{bp})$ for minDE. The resulting PCR products were cloned into pTH1227 to obtain pTH1369 $\left(\mathrm{P}_{\mathrm{tac}}-\min C\right)$, pTH1228 $\left(\mathrm{P}_{\mathrm{tac}}-\min D\right)$, pTH1229 ( $\left.\mathrm{P}_{\text {tac }}-\min E\right), \quad$ pTH1230 $\left(\mathrm{P}_{\text {tac }}-\min C D\right), \quad$ pTH1231 $\left(\mathrm{P}_{\text {tac }}-\min C D E\right)$ and pTH1587 $\left(\mathrm{P}_{\text {tac }}-\operatorname{minDE}\right)$. Transfer of these plasmids to S. meliloti Rm1021 resulted in strains SmK701 (pTH1228), SmK702 (pTH1229), SmK703 (pTH1230), SmK704 (pTH1231), SmK705 (pTH1369) and RmP321 (pTH1587), respectively.

To measure min gene expression and identify promoter(s) in the minCDE region, an 844 bp DNA fragment from 837 bp upstream of min $C$ was PCR-amplified using primers AB32663/AB32664 and cloned into pUCP30T (Schweizer et al., 1996). The SphI-KpnI fragment from the resulting plasmid (the promoter region) was then cloned into the reporter plasmid pFUS1 to give pTH1261 (Fig. 1a). Another 839 bp DNA fragment carrying the $\min C \mathrm{ORF}$ and the $\min C$ and $\min D$ intergenic region was obtained by PCR using primers AB32919/ AB32920 and then cloned upstream of gusA in pFUS1 to obtain pTH1273 (Fig. 1a). Following transfer of pTH1261 and pTH1273 into Rm1021, strains SmK712 and SmK710 were obtained, respectively. Plasmid pTH1445 was constructed for amplifying minC mRNA for primer extension. A DNA fragment carrying $\min C$ and the $1 \mathrm{~kb}$ region upstream of $\min C$ was PCR-amplified using primer AB32664/ AB31697 and cloned into the ApaI/XbaI sites in pBluescript SK (Stratagene) to obtain pTH1423. The S. meliloti DNA was then subcloned into the KpnI/XbaI sites in pFUS1 to obtain pTH1445. Strain SmK857 was obtained after transfer of pTH1445 into S. meliloti Rm1021. 
Table 1. Bacterial strains and plasmids

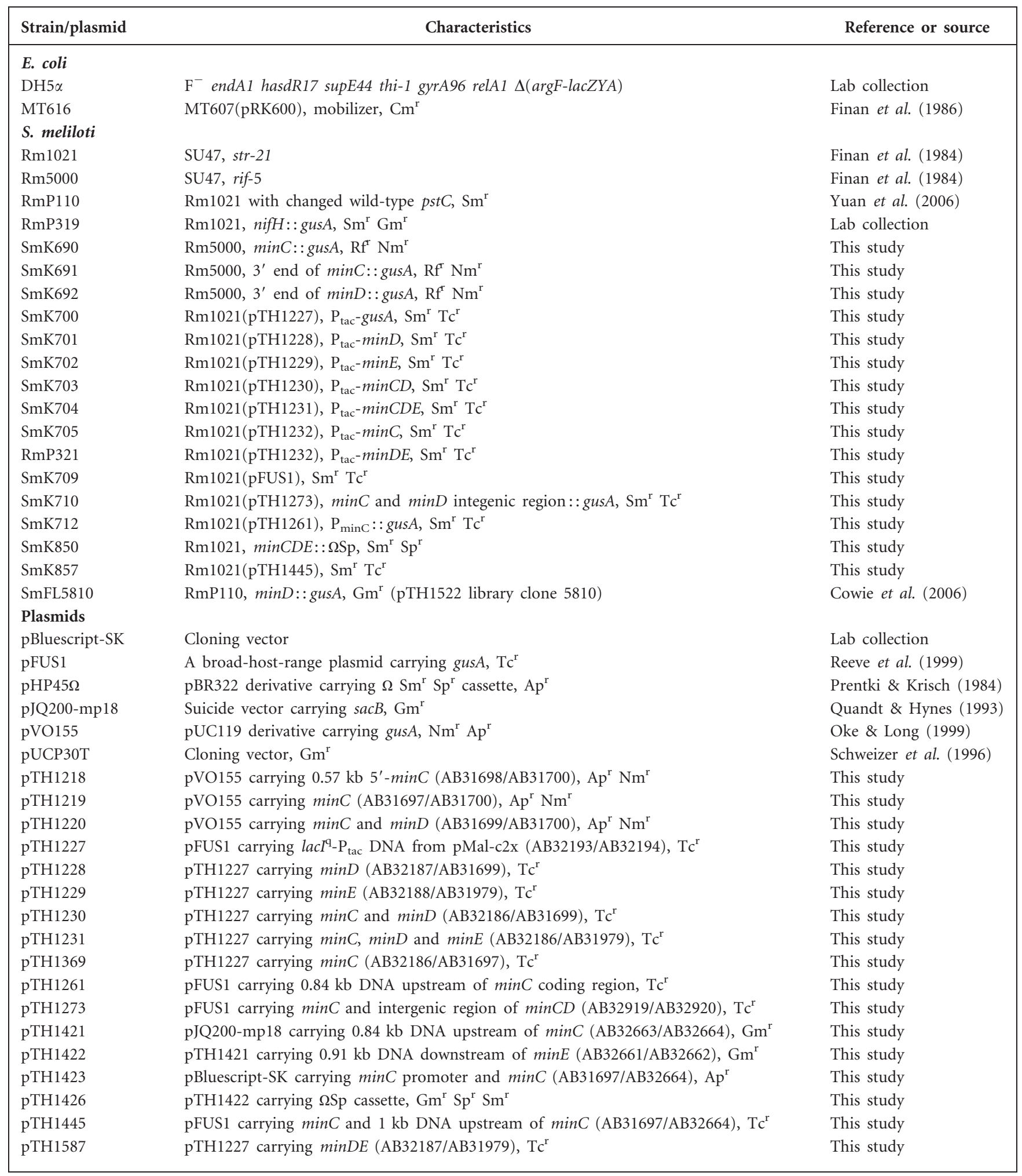

Ap, Ampicillin; Gm, gentamicin; Nm, neomycin; Rf, rifampicin; Sm, streptomycin; Sp, spectinomycin; Tc, tetracycline.

RNA isolation and primer extension. S. meliloti SmK857 containing pTH1445 was grown in $20 \mathrm{ml} \mathrm{LBmc}$ and M9 glucose to an $\mathrm{OD}_{600}$ between 0.4 and 0.6 . After addition of $2 \mathrm{ml} 5 \%(\mathrm{v} / \mathrm{v})$ phenol in ethanol (Bernstein et al., 2002), cells were collected by centrifugation at $2500 \mathrm{~g}$ for $10 \mathrm{~min}$ at $4{ }^{\circ} \mathrm{C}$. The cell pellet was resuspended in $325 \mu \mathrm{l} 10 \mathrm{mM}$ sodium acetate $(\mathrm{pH} 4.2)$ buffer containing $0.3 \mathrm{M}$ 
Table 2. Oligonucleotides used in this work

Restriction and ribosome-binding sites that were engineered into the primers are shown in bold or underlined respectively.

\begin{tabular}{|ll|}
\hline Oligonucleotide & \multicolumn{1}{c|}{ Sequence $\mathbf{( 5}^{\prime} \mathbf{- 3}^{\prime} \mathbf{)}$} \\
\hline AB31697 & CCCCTCTAGAATCCGATAAATC \\
AB31698 & CCCTCTAGAAGCGTCCCGTAGATATG \\
AB31699 & CGGGTCTAGATTATGCTGCCCTCCGTCCGAATATCTTG \\
AB31700 & CCCCGGATCCGCTAGCACCAAAGTGCTAACAGAC \\
AB31979 & CGCCTCTAGACGGGGCTCGGTGATGCTG \\
AB32186 & GGCAAGATCTAAGGAACGAAGATGACCAAAG \\
AB32187 & CGCCAGATCTACAGGAGCGGGAAGAT \\
AB32188 & GGGCAGATCTAAGGAGGGCAGCATGAGCATTTTC \\
AB32193 & GCGCGTCGACAAGCTTGAATGGTGCAAAAC \\
AB32194 & CCCCTCGAGGTGAAGTGCTCGTGAAAAC \\
AB32661 & GCTCGAGCTCCACGAGAAAACGGTGAAACATC \\
AB32662 & GGCGGGATCCGCAATGGCAACCGGATGGATAAC \\
AB32663 & GCGCGGATCCTGGTCATCTTCGTTAATTAT \\
AB32664 & TTATCTCGAGGGCCCGGATCACCTCATCCGCAATTCAAA \\
AB32919 & TAACGAATTCGACCAAAGTGCTAACAGA \\
AB32920 & GCAACTGCAGCTACTTTCGCCATCTTC \\
ML2050 & GAGCGGCCCTTGTTGTGGATCGAGCGAGCGTCTGTTAGCA \\
ML9882 & GGTCCGTTTCGCCTCCGCATGACGTG \\
\hline
\end{tabular}

sucrose and $50 \mathrm{mM}$ EDTA. Following addition of $375 \mu \mathrm{l}$ lysis buffer $(2 \%, w / v$, SDS in $10 \mathrm{mM}$ sodium acetate, $\mathrm{pH} 4.2)$, the mixture was incubated at $65^{\circ} \mathrm{C}$ for $5 \mathrm{~min}$. Pre-warmed acidic phenol $(700 \mu \mathrm{l}$, $65^{\circ} \mathrm{C}, \mathrm{pH} 4.2$ ) was added to the lysate and incubation was continued for a further $5 \mathrm{~min}$ with vortexing every $1 \mathrm{~min}$. Total RNA was extracted with the acidic phenol twice, phenol/chloroform $(50: 50)$ twice and then chloroform, and the RNA was precipitated with ethanol. The RNA was treated with RNase-free DNase I at $37^{\circ} \mathrm{C}$ for $30 \mathrm{~min}$ and then purified using a Qiagen RNeasy mini column, according to the manufacturer's instructions. The purity and quality of the RNA were checked by electrophoresis through a $1.2 \%$ agarose TBE gel.

To identify the transcriptional start site through primer extension, primers ML2050 and ML9882 were end-labelled with $\gamma-{ }^{32} \mathrm{P}-\mathrm{ATP}$ (Amersham) by using T4 polynucleotide kinase (New England Biolabs) at $37^{\circ} \mathrm{C}$ for $45 \mathrm{~min}$. Unincorporated label was removed by passing the labelling mixture through Qiagen oligopurification columns. The primer extension reaction was carried out as described previously (Yuan et al., 2006). The primer extension product was loaded onto a $6 \%$ acrylamide/7 $\mathrm{M}$ urea sequencing gel and run alongside a sequencing ladder generated by using the same primer with plasmid template pTH1423 and the Sequenase Version 2 DNA Sequencing kit (USB).

$\boldsymbol{\beta}$-Glucuronidase activity assay. To measure expression of the gusA gene encoding $\beta$-glucuronidase (GusA), S. meliloti cultures were grown up in 96 deep-well plates (ABgene) in $0.5 \mathrm{ml} \mathrm{LBmc}$ medium with antibiotics, and then subcultured into $150 \mu \mathrm{LBmc}$ or M9 media in 96-well plates (Costar). After $16 \mathrm{~h}$ growth in LBmc or $36 \mathrm{~h}$ growth in M9 media, $5 \mu \mathrm{l}$ cultures were transferred to $95 \mu \mathrm{l}$ assay buffer $(50 \mathrm{mM}$ sodium phosphate, $\mathrm{pH} 7.0,1 \mathrm{mM}$ EDTA, $0.0125 \%$, w/v, SDS and $0.438 \mathrm{mg} p$-nitrophenyl- $\beta$-glucuronide $\mathrm{ml}^{-1}$ ) in 96-well plates. The reaction was stopped with $100 \mu \mathrm{l} 1 \mathrm{M}$ $\mathrm{Na}_{2} \mathrm{CO}_{3}$ after $1 \mathrm{~h}$. $A_{405}$ was measured using a Safire microplate reader (Tecan). GusA specific activities were calculated using the equation: specific activity $=A_{405} \times 1000 / 60 \times 0.005 \times \mathrm{OD}_{600}$.
For nodule extracts, GusA specific activity was calculated using the equation: $A_{405} \times 1000 \times(\text { time }, \mathrm{min})^{-1} \times(\text { volume, } \mathrm{ml})^{-1} \times(\mathrm{mg}$ protein $)^{-1}$.

Plant tests. Symbiotic $\mathrm{N}_{2}$ fixation was assessed using alfalfa (Medicago sativa) grown under nitrogen-deficient conditions in Leonard assemblies as described previously (Finan et al., 1986). Plants were harvested 28 days after inoculation and shoot dry weights were determined following drying in an oven. Measurement of GusA activity in nodules and histochemical staining for GusA were performed as described by Yuan et al. (2006). To determine the viable cell numbers in nodules, fresh nodules were surface-sterilized for $5 \mathrm{~min}$ in $2.5 \%$ sodium hypochlorite, rinsed three times in $0.85 \%(\mathrm{w} / \mathrm{v}) \mathrm{NaCl}$ and then put into ice-cold MMS buffer $\left(20 \mu \mathrm{mg}^{-1}\right)$ containing $40 \mathrm{mM}$ MOPS (pH 7.0), $20 \mathrm{mM} \mathrm{KOH}$, $2 \mathrm{mM} \mathrm{MgSO}_{4}$ and $0.3 \mathrm{M}$ sucrose. The nodules were crushed and then centrifuged for $2 \mathrm{~min}$ at $400 \mathrm{~g}$. The supernatant was diluted serially in $0.85 \% \mathrm{NaCl}$ and then plated onto LB agar plates.

Environmental scanning electron microscopy (ESEM). ESEM was performed as described previously (Sibley et al., 2006). Briefly, primary fixation of mid-exponential-phase LB-grown cells was done at room temperature for $30 \mathrm{~min}$ in $2 \mathrm{ml} 0.2 \mathrm{M}$ sodium cacodylate buffer ( $\mathrm{pH} 7.4)$ containing $2.5 \%(\mathrm{v} / \mathrm{v})$ glutaraldehyde. Bacteroids were fixed in MMS buffer containing $2.5 \%$ glutaraldehyde for $1 \mathrm{~h}$. Fixed cells were washed five times in $\mathrm{ddH}_{2} \mathrm{O}$ and then $1 \mu \mathrm{l}$ was spotted onto a gold-coated cover glass ( $5 \mathrm{~nm}$ thick) that was mounted on an ESEM stub with conductive glue. Wet samples were viewed with an Electronscan 2020 Environmental Scanning Electron Microscope at 2.4-4.0 Torr with an accelerating voltage of $20-30 \mathrm{KeV}$.

Transmission electron microscopy. Primary fixed samples were washed twice in acetate/veronal buffer $(59 \mathrm{mM}$ sodium acetate, $35 \mathrm{mM}$ sodium barbital, $145 \mathrm{mM} \mathrm{NaCl}$ and $12 \mathrm{mM} \mathrm{CaCl}_{2}, \mathrm{pH} 6.1$ ), resuspended in the same buffer containing $1 \%(\mathrm{w} / \mathrm{v})$ osmium tetroxide and then incubated at room temperature for $4 \mathrm{~h}$. The cells were then washed twice in the acetate/veronal buffer and resuspended in 


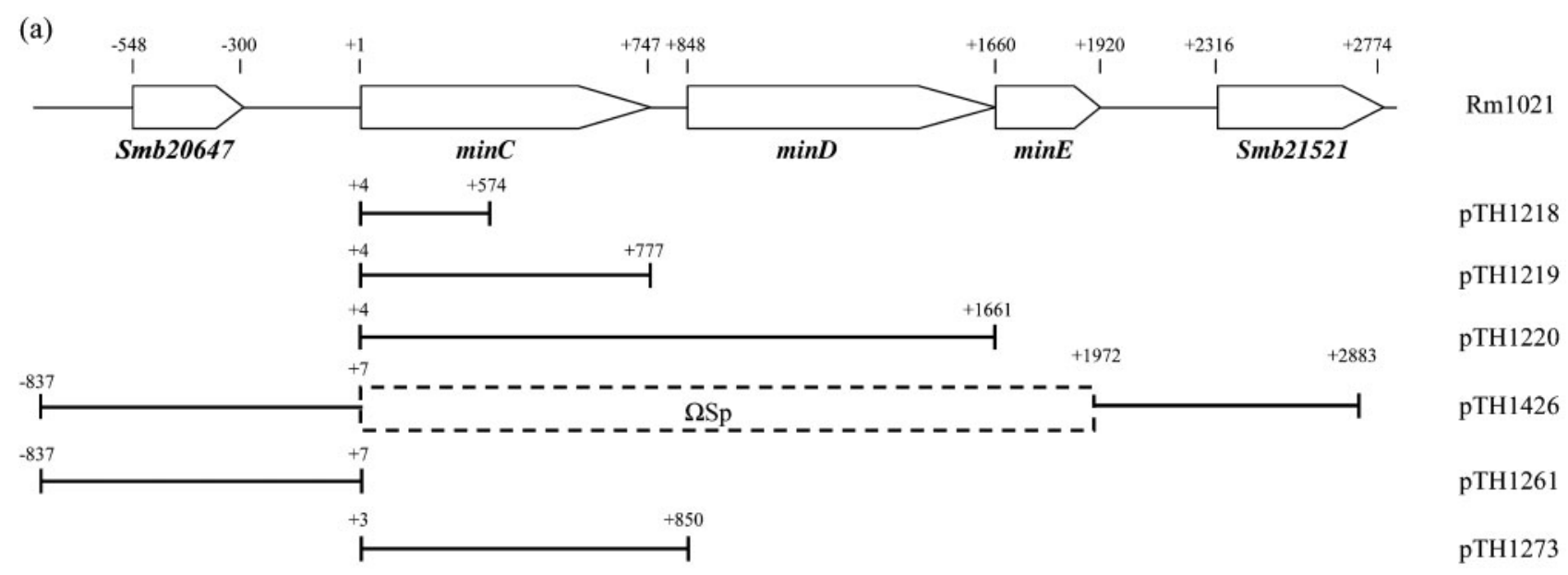

(b)

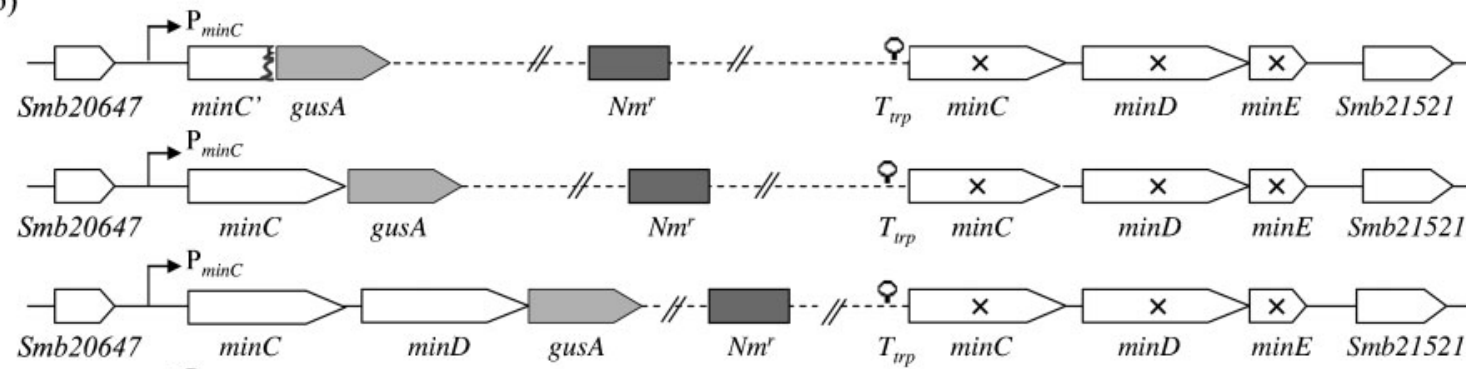

SmK690

SmK691

SmK692

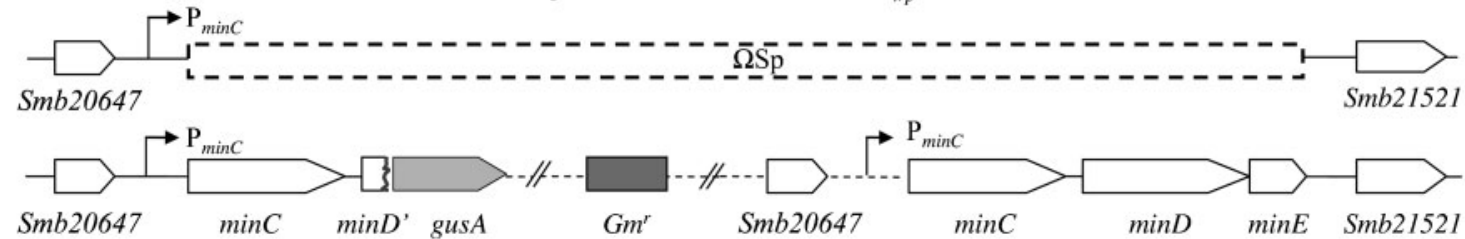

SmK850

SmFL5810

Fig. 1. Schematic diagram of the minCDE region on the megaplasmid pSymB of S. meliloti. (a) DNA fragments (solid line) were PCR-amplified and cloned to obtain the pVO155 derivatives pTH1218, pTH1219 and pTH1220, the pFUS1 derivatives pTH1261 and pTH1273, and the pJQ200-mp18 derivative pTH1426. The minCDE genes were replaced by a $\Omega$ Sp cassette in $\mathrm{pTH} 1426$. The +1 above $\operatorname{minC}$ refers to nt 1 of the translational start codon. (b) Transfer of the constructs into $S$. melilotigenerated $\min C D E$ mutants SmK690 and SmK850, minDE mutant SmK691 and minE mutant SmK692. The trp terminator (stem-loop) blocks transcription from the plasmid backbone. The $\min C$ promoter is indicated $\left(P_{\min C}\right.$, arrow). The structure of the $\min D::$ gusA gene fusion in SmFL5810 is also indicated.

$2 \%(\mathrm{w} / \mathrm{v})$ Nobel Agar $\left(45^{\circ} \mathrm{C}\right)$ and cooled on a glass slide. Cells embedded in the agar cubes $\left(1 \mathrm{~mm}^{3}\right)$ were then stained with $0.5 \%$ (w/v) uranyl acetate in the acetate/veronal buffer at $4{ }^{\circ} \mathrm{C}$ for $12 \mathrm{~h}$. Samples were dehydrated at room temperature with sequential washes of increasing ethanol concentrations and finally with propylene oxide. Infiltrated samples were embedded in Spurr's resin (Spurr, 1969) and 60-90 nm sections were cut with an Ultracut Microtome. Thin sections were post-stained in a $1 \%(\mathrm{w} / \mathrm{v})$ aqueous uranyl acetate solution for $20 \mathrm{~min}$ on carbon-coated copper EM grids (100 mesh) that had been previously covered with $0.3 \%(\mathrm{w} / \mathrm{v})$ Formvar. Sections were then post-stained with Reynold's lead citrate for 6 min.

\section{RESULTS}

\section{Structure and expression of the minCDE genes}

The organization of the $\min C, \min D$ and $\min E$ on the $S$. meliloti pSymB megaplasmid suggests that these genes are transcribed as an operon, $\min C D E$. There is a $101 \mathrm{bp}$ region between $\min C$ and $\min D$ which contains a 43 bp partial RIME element (Østerås et al., 1995) and there is a single nucleotide overlap between $\min D$ and $\operatorname{minE}$ (schematically outlined in Fig. 1). To identify promoters associated with these genes, an 844 bp DNA fragment encompassing the region upstream from the $\min C$ translational start codon and a $847 \mathrm{bp}$ DNA fragment containing the $\min C$ ORF and the $\min C-\min D$ intergenic region were cloned into the replicating gusA reporter plasmid pFUS1 to generate plasmids pTH1261 and pTH1273, respectively (Fig. 1). Analysis of GusA activity from S. meliloti strains carrying these plasmids (Fig. 2a) demonstrated strong promoter activity (20-fold above background) from upstream of $\min C$ (SmK712). The promoter activities from cells grown in both rich medium (LB) and minimal medium (M9-glucose) were comparable although the growth rate for $S$. meliloti was 
(a)

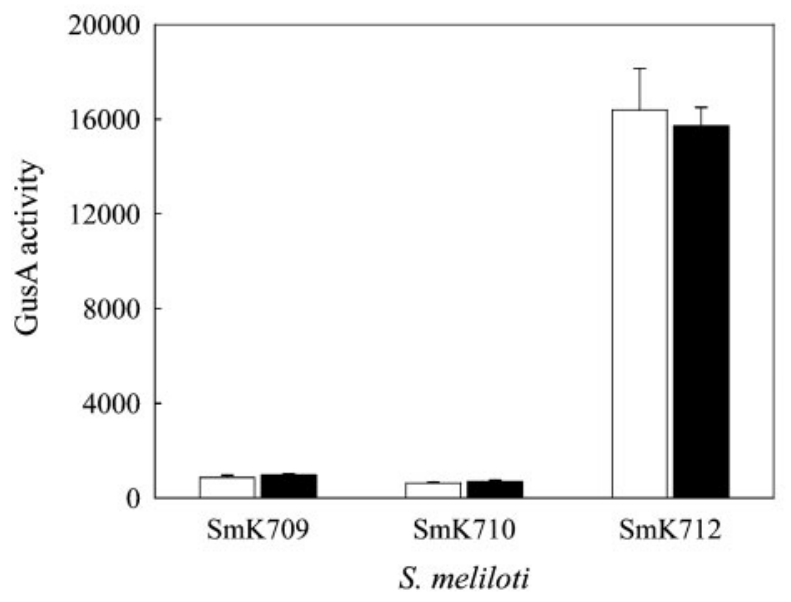

(b)

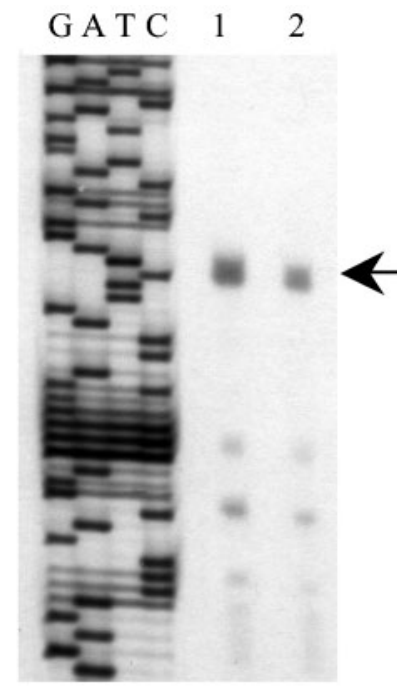

(c)

$$
-35
$$

$-10$ CCCAGCCGTCAGCCCTGTGCAAGCTCCCATCGTCACCATGCTGCCT $+1$

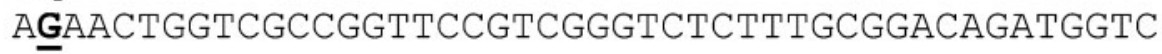
TCGCACGTCACGGAAATCTCCACGTCATGCGGAGGCGAAACGGACC
Extension primer ML9882
GAAGATCAGGCAAAGAAGGAGGCCCATTACCATTTGTAACCATG
GCTCGCCTACATCTTGGCAACCAATAA PTAACFAAGATGA start TGCTAACAGACGCTCGCTCGATCCGCATCAATCAAGGGCCGCTCCTT Extension primer ML2050

Fig. 2. Expression of minCDE genes in S. meliloti. (a) Cultures were grown in LBmc (white bars) or M9-glucose media (black bars) in 96-well plates as described in Methods. GusA activity is represented as $A_{405} \times 1000 /$ time (min) $\times$ sample volume $(\mathrm{ml}) \times \mathrm{OD}_{600}$. SmK709 contained pFUS1 as control, SmK710 contained pTH1273, i.e. pFUS1 with the minC gene and minCD intergenic region, and SmK712 contained pTH1261, i.e. pFUS1 with the minC promoter region. (b) Determination of transcriptional start sites of the $\operatorname{minC}$ promoter in $S$. meliloti through extension of ${ }^{32} \mathrm{P}$-labelled ML9882 primer. Lanes: 1, RNA isolated from SmK857 cells grown in LBmc; 2, RNA isolated from SmK857 cells grown in M9 glucose. (c) Sequence of the $\min C$ promoter region, showing the transcriptional start $(+1)$ site, and -35 and -10 regions (underlined). Predicted CtrA binding sites are boxed and underlined sequences show the locations of extension primers used for transcriptional start site mapping. Data for primer ML2050 are not shown.

about twofold slower in M9 minimal medium compared to LBmc. Consistent with an absence of promoter activity, only background GusA activity was observed from constructs carrying the $\min C-\min D$ intergenic region (SmK710). These data demonstrated that, under the conditions examined, transcription emanated from upstream of $\min C$. To map the transcriptional start site(s) upstream of $\min C$, we used primer extension and two distinct primers (ML9882, Fig. 2b; ML2050, data not shown). Using mRNA extracted from both LBmc- and M9-glucose-grown cells, a transcript initiating from $174 \mathrm{nt}$ upstream from the $\min C$ start codon was identified in both extension reactions. The deduced -35 and -10 hexanucleotide promoter sequences, $5^{\prime}$-GCCTGC-N ${ }_{17}$-CCATGC-3', showed little similarity to the recently derived $S$. meliloti promoter consensus sequences 5 '-CTTGAC- $\mathrm{N}_{17}$-CTATAT-3', particularly within the more conserved -35 region (MacLellan et al., 2006). We note that the $174 \mathrm{nt}$ untranslated region is relatively large for $S$. meliloti genes. This could reflect the presence of regulatory sequences and, in this respect, it is 
interesting that two possible CtrA protein-binding sites (Barnett et al., 2001) are positioned in this region (Fig. 2c), implying that the CtrA protein might be involved in regulation of $\min C D E$ expression in $S$. meliloti.

\section{S. meliloti minCDE genes are dispensable for growth}

To investigate whether $\min C D E$ are required for cell viability, we sought to construct a strain where these genes were deleted and replaced with the $\Omega S p$ cassette. We confirmed that the min genes were absent from the resulting strain SmK850 (Rm1021 $\triangle \min C D E:: \Omega S p$ ) by PCR, while a fragment from upstream of $\min C$ to the $\Omega$ Sp gene was readily amplified in four separate mutants. Additional min mutant derivatives were made via a single cross-over recombination between plasmids carrying fragments from the min gene region and the $\min$ genes in the genome. These co-integrates readily generated single cross-over polar mutations in the $\min C$ gene in strain $\operatorname{SmK690}\left(\min C^{-} \min D^{-} \min E^{-}\right)$, in the $\min D$ gene in strain SmK691 $\left(\min ^{-} \operatorname{minE}^{-}\right)$and in the $\min E$ gene in strain SmK692 ( $\left.\min ^{-}\right)$(see Fig. 1b).

The growth of the resulting strains in LBmc and M9 media was examined and the viability of these cultures was determined by plating dilutions onto LB agar (data not shown). In addition, the effects of the mutations on cell structure were determined by examining the cells by phasecontrast microscopy and by both scanning and transmission electron microscopy (Fig. 3).

With the exception of the minE mutant strain SmK692 which is described below, the various min mutants grew at similar rates $\left(\mathrm{OD}_{600}\right)$ and had similar cell viability to their parent strains. The morphologies of SmK850 $(\triangle \min C D E:: \Omega S p) \quad$ (Fig. 3b), SmK690 $\left(\min C^{-} \min ^{-}\right.$ $\left.\min E^{-}\right)$(data not shown) and SmK691 $\left(\min D^{-} \min E^{-}\right)$ (Fig. 3c) were indistinguishable from the rod-shaped, 1-2 $\mu \mathrm{m}$ long wild-type cells (Fig. 3a). This differs from the minicell phenotype observed with E. coli minCDE and minDE mutants (de Boer et al., 1989). Strikingly the cells from the $\min E^{-}$mutant strain SmK692 were swollen and branched with single or multiple asymmetric septa (Fig. 3d). This phenotype also contrasts with the cell filamentation phenotype seen with an E. coli minE mutant (de Boer et al., 1989). Transmission electron micrographs showed that wild-type S. meliloti cells had normal mid-cell invaginations and an intact membrane surrounding the entire cell (Fig. 3e). The minE cells were very different from wild-type (Fig. 3f), as seen by the membrane connectivity of (a) Wild-type

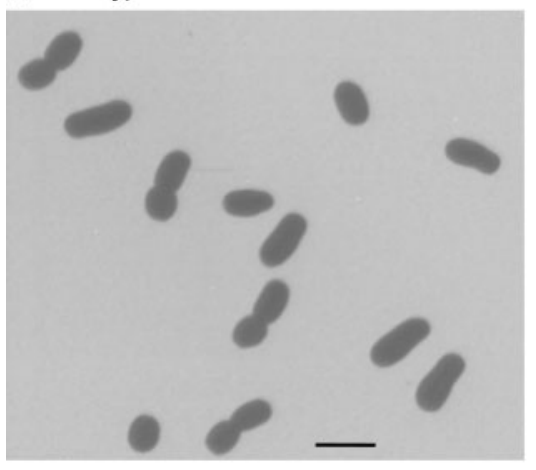

(d) $\min E^{-}$

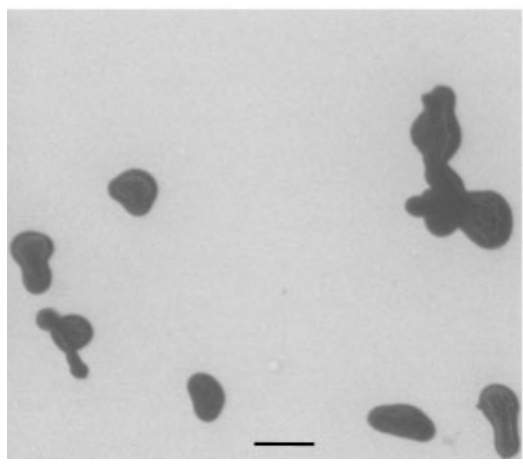

(b) $\triangle \min C D E:: \Omega S p$

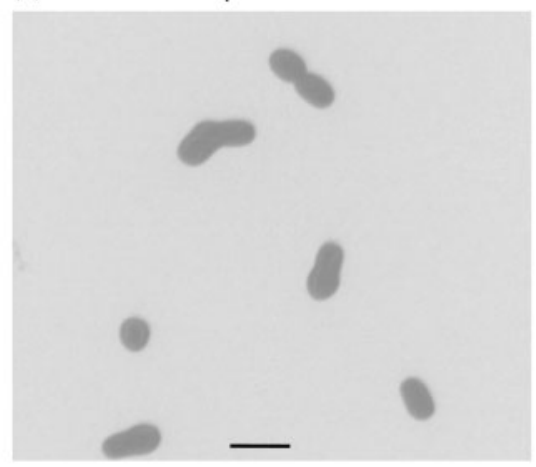

(e) Wild-type

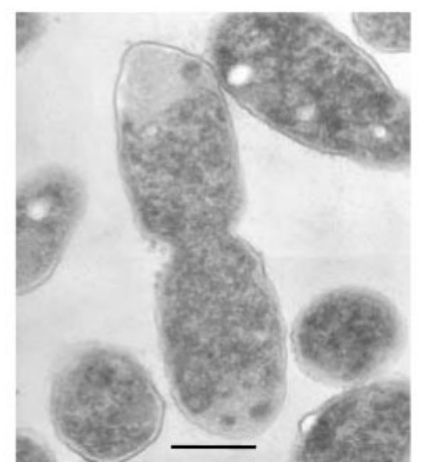

(c) $\min D^{-} \min E^{-}$

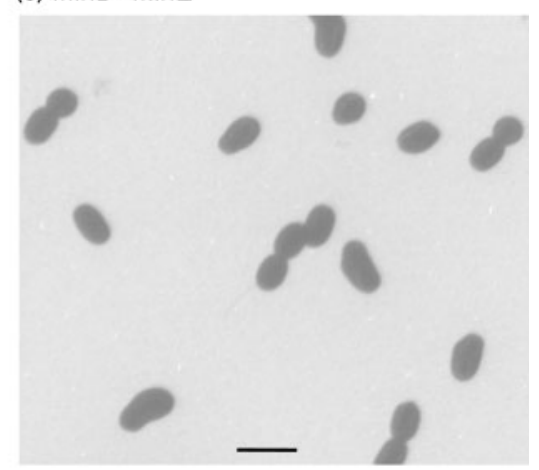

(f) $\min E^{-}$

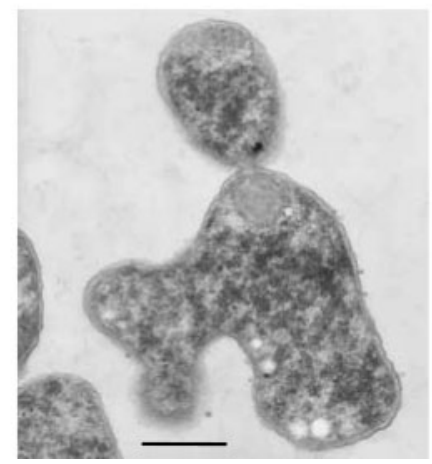

Fig. 3. Cell morphology of $S$. meliloti strains. Environmental scanning electron micrographs of wild-type Rm5000 (a), minCDE mutant SmK690 (b), minDE mutant SmK691 (c) and minE mutant SmK692 (d); transmission electron micrographs of Rm5000 (e) and SmK692 (f). Cells were grown in LBmc medium to mid-exponential phase and processed for electron microscopy as described in Methods. Bars, $2 \mu \mathrm{m}$ (a, b, c, d) and $0.4 \mu \mathrm{m}(\mathrm{e}, \mathrm{f})$. 
the cytoplasm with shapes never seen in the wild-type sections. Thus, the branched cells appeared to represent individual bacteria with atypical morphology.

\section{Symbiotic phenotype of S. meliloti min mutants}

The symbiotic phenotype of the $S$. meliloti wild-type and min mutant strains was examined following their inoculation onto alfalfa seedlings. The min mutants formed wildtype-like pink nodules. With the exception of the min $E^{-}$ mutant SmK692 (discussed below), the dry weights of the alfalfa plants inoculated with the mutants were similar to those inoculated with the wild-type strains (Table 3). The dry weights of alfalfa inoculated with $\operatorname{minE}^{-}$mutant SmK692 were $30 \%$ of the parent Rm5000, while the uninoculated plants were less than $5 \%$ of the wild-type dry weight (Table 3). Thus the minE mutation resulted in a large decrease in symbiotic $\mathrm{N}_{2}$ fixation.

To determine whether the min mutations reduced the viability of the bacterial cells in nodules, 4 -week-old nodules were crushed and the resulting cell suspensions were plated onto LB agar. The viable cell numbers of SmK850 $(\triangle \min C D E)$ and $\operatorname{SmK} 691\left(\min D^{-} E^{-}\right)$nodules were similar to that of the wild-type $\left.\left[9 \times 10^{7} \text { (g nodule) }\right)^{-1}\right]$, while the number of viable cells in SmK692 $\left(\operatorname{minE}^{-}\right)$nodules was slightly reduced $\left.\left[3 \times 10^{7} \text { (g nodule }\right)^{-1}\right]$ relative to the wildtype. The morphology of the bacteroids was examined using ESEM. Wild-type strain Rm1021 bacteroids showed a heterogeneous morphology as described by Vasse et al. (1990) with enlarged filaments and Y shapes of 3-8 times the length of vegetative cells, and the various min mutant strains, SmK690, SmK850, SmK691 or SmK692, were indistinguishable from the wild-type (data not shown). We suggest that the reduced $\mathrm{N}_{2}$-fixation phenotype of the $\min E^{-}$mutation is related to the aberrant cell division phenotype that results when $\min C$ and $\min D$ are expressed in the absence of minE. Our results demonstrate that the min genes are not essential for the development of $\mathrm{N}_{2}$-fixing nodules.

\section{Expression of $\min$ genes in nodules}

The lack of a symbiotic phenotype for the minCDE deletion mutant coupled with the reduced fix phenotype of the $\min E^{-}$mutant prompted us to investigate the expression of these genes in nodules. Expression of the minCDE genes in nodules was measured following the inoculation of alfalfa seedlings with the minD::gusA reporter gene fusion in strain SmFL5810. The single cross-over that generated this strain also reconstituted a wild-type minCDE gene region (see Fig. 1b). As a control we employed strain RmP319 carrying a nifH::gusA gene fusion since nifH is highly expressed in bacteroids (Barnett et al., 2004). Examination of nodules 4 weeks after inoculation revealed that the nifH gene was highly expressed with a GusA specific activity of $7739 \pm 311$ while the GusA specific activity from SmFL5810 nodule extracts was $1675 \pm 26$ or about $22 \%$ that of nifH. These data demonstrate that the minCDE genes are expressed in nodules.

To investigate whether min gene expression was uniform throughout the nodule, longitudinal sections of nodules were examined following histochemical staining for GusA. The staining revealed that expression of the nifH gene occurred in the previously described interzone II to III (Vasse et al., 1990) (data not shown), as reported by Labes et al. (1993) and Soupene et al. (1995). In contrast, the minD gene was expressed in all regions of the nodule containing the bacteria (SmFL5810, minD:: gusA), including infection zone II (data not shown).

\section{Overexpression of min genes in S. meliloti generated different phenotypes}

With the exception of the aberrant cell division phenotype that resulted from the $\min E^{-}$mutation, the expression data and $\min$ mutant phenotypes were not informative as to a direct role for min genes in cell septation in S. meliloti. We therefore examined whether expressing the $\min$ genes from a strong plasmid-borne promoter would affect the cell morphology and viability of S. meliloti. Individual or

Table 3. Symbiotic phenotypes of $S$. meliloti strains

Alfalfa plants were harvested 28 days after inoculation. The dry weights are shoot dry weights (mean \pm SEM). All viable nodule isolates obtained from plants inoculated with SmK690, SmK691 and SmK692 were $\mathrm{Nm}^{\mathrm{r}}$. All viable nodule isolates obtained from plants inoculated with RmP319, SmFL5810 were $\mathrm{Gm}^{\mathrm{r}}$, and all isolates from SmK850 inoculated plants were $\mathrm{Sp}^{\mathrm{r}}$.

\begin{tabular}{|c|c|c|c|}
\hline Strain & Relevant genotype & Dry weight (mg per plant) & Percentage $^{\star}$ \\
\hline Rm1021 & $\mathrm{Sm}^{\mathrm{r}}$ derivative of wild-type SU47 & $111.3 \pm 7.3$ & 100.0 \\
\hline SmK690 & $\mathrm{Rm} 5000 \min ^{-} \min ^{-} \min ^{-}$ & $97.2 \pm 3.6$ & 87.3 \\
\hline SmK691 & $\operatorname{Rm} 5000 \min ^{-} \min E^{-}$ & $89.1 \pm 2.2$ & 80.0 \\
\hline
\end{tabular}

${ }^{\star}$ The percentages were calculated by comparison with the value for the wild-type strain Rm1021. 
combinations of min genes with ribosome-binding sites were cloned downstream of the $\mathrm{P}_{\text {tac }}$ promoter in the expression vector $\mathrm{pTH} 1227$ which also carries the $\operatorname{lacl}^{\mathrm{q}}$ gene upstream of the promoter. These cell structures of IPTGinduced S. meliloti cells carrying these plasmids were examined by ESEM, and cell viability was evaluated by diluting cultures of known $\mathrm{OD}_{600}$ and plating onto LB agar. In the absence of added IPTG, alterations to the wild-type cell structures were not observed. As the gusA gene is located downstream of the $\mathrm{P}_{\mathrm{tac}}$ promoter in pTH1227, we first examined S. meliloti cells overexpressing gusA alone. These cells resembled the short rods of wild-type Rm1021 (SmK700, Fig. 4a, b) and their viability was the same as wild-type cells (data not shown). When the $\min C$ gene was expressed in pTH1227, several cell phenotypes were observed, including wild-type-like short rods, filaments, and swollen and branched cells (SmK705, Fig. 4c). The viability of these cells was similar to the wild-type. Expression of the minD gene from pTH1227 generated multi-branched cells (Fig. 4d, e) and the cell viability of these cultures was over 10000 -fold lower than the wild-type. Hence overproduction of MinD had a much more inhibitory effect on cell growth and division than overproduction of MinC. A similar inhibitory effect and a filamentation phenotype was observed in E. coli upon increased synthesis of MinD (de Boer et al., 1989). Neither cell division nor cell viability appeared compromised in cells overexpressing $\min E$ (SmK702, Fig. 4a, f). When minE was overexpressed with $\min D$ in $\mathrm{RmP321}$, a mixture of wild-type and branching cells was generated (Fig. $4 \mathrm{k}, \mathrm{l}$ ) and the viability of these cells was about tenfold higher than the cells overexpressing $\min D$ alone. These data indicated that MinE could relieve the inhibitory effect of MinD on cell division and growth, although it is also possible that $\min D$ expression levels were reduced in these cells.

Expression of both minC and minD from pTH1227 (SmK703 Fig. $4 \mathrm{~g}, \mathrm{~h}$ ) generated a branching cell morphology with the reduced cell viability observed for cells in which $\min D$ alone was overexpressed. The overexpression of $\min C D E$ (SmK704, Fig. 4i, j) from pTH1227 also generated the cell morphology and cell viability phenotypes observed from when $\min D$ alone was overexpressed (Fig. 4g, h). We note that for these constructs the cell growth, cell viability and cell morphology were not affected under non-inducing conditions.

\section{Overexpression of S. meliloti Min proteins in E. coli}

The morphology of E. coli DH5 $\alpha$ cells carrying the various pTH1227 min derivatives was examined after IPTG-induced expression of min gene expression. Without IPTG induction all cells appeared like wild-type. IPTG-induced expression of the gusA gene from pTH1227 did not alter the rodshaped morphology of E. coli (Fig. 5a). IPTG-induced overexpression of the entire minCDE operon resulted in a large number of short filaments and minicells (Fig. 5f), a classic minicell phenotype of E. coli (de Boer et al., 1989). When viewed by ESEM, the same minicell phenotype was also observed when the $S$. meliloti minE gene was expressed in E. coli (Fig. 5d). In addition, expression of the $\min D$ or $\min C D$ genes in $E$. coli caused formation of long, nonseptate filaments (Fig. 5c, e), whereas S. meliloti MinC produced various sizes of filaments in E. coli (Fig. 5b). Filamentation resulting from overexpression of $S$. meliloti MinC and MinCD proteins was the same as that resulting from E. coli Min proteins (de Boer et al., 1989). Taken together, the morphological changes in E. coli cells resulting from overexpression of the $S$. meliloti Min proteins imply that the S. meliloti and E. coli MinCDE proteins act similarly with respect to cell division.

\section{DISCUSSION}

We have demonstrated that the minCDE genes are not essential for cell viability or cell division in S. meliloti. Thus we readily obtained both $\operatorname{minCDE}$ deletion and single crossover insertion mutants, whereas in a separate study, we were unable to recover single cross-over recombinants in the par $A B$ genes encoding chromosome partitioning proteins ParA and ParB of S. meliloti (Cowie et al., 2006). The parAB genes are essential in Caulobacter crescentus (Figge et al., 2003; Mohl et al., 2001). Our data clearly show that the $\mathrm{min}$ genes are expressed in free-living cells, and both the cell phenotype of the minE mutant and that of cells expressing minD from the $\mathrm{P}_{\text {tac }}$ promoter are consistent with these genes playing a role in cell septa location/formation. In the absence of MinE, it appears that the MinC and MinD proteins interfere with septum formation. This is consistent with the E. coli model where MinE prevents the MinCD division inhibitor from accumulating at the midcell, while permitting it to block division at other unwanted sites along the length of the cell (Shih et al., 2003). In E. coli, the Min system prevents septation at potential division sites near cell poles without blocking septum formation at the desired midcell location. MinC interacts with the division protein FtsZ to prevent formation of stable FtsZ rings, a vital first step in assembly of the division machinery. MinE is responsible for giving site specificity to MinC, limiting its activity to the sites away from the desired midcell. MinD is responsible for the membrane association of MinC and MinE (Errington et al., 2003). According to the E. coli Min model, deletion of $S$. meliloti minCDE genes, or a polar $\min C$ mutation or a polar minD mutation, should result in a minicell phenotype which was not observed in this study. Instead, the mutant cells were indistinguishable from wild-type. Alternatively, expression of the genomic copy of the $\min C$ and $\min D$ genes in the absence of the minE gene in S. meliloti would be predicated to produce long filaments, but cells actually showed a large, swollen and branched morphology (Fig. 4g, h).

Deletion of the min genes in E. coli and B. subtilis generates a minicell phenotype in which a large fraction of cells divide at polar positions of the cell instead of the middle (de Boer et al., 1989; Cha \& Stewart, 1997). In contrast, the Synechocystis $\triangle \min C D E$ mutant displays spiralled, heartshaped cells and minicells (Mazouni et al., 2004). The 
(a) Wild-type

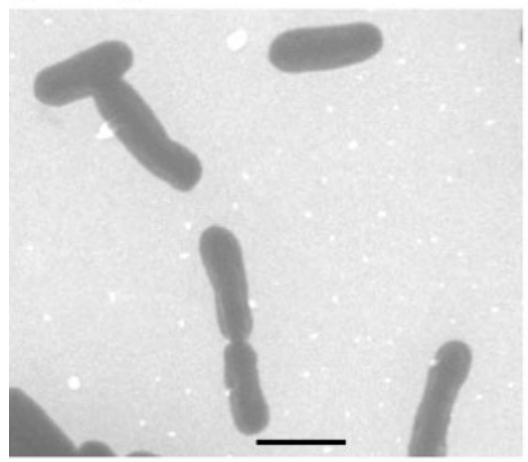

(d) + MinD

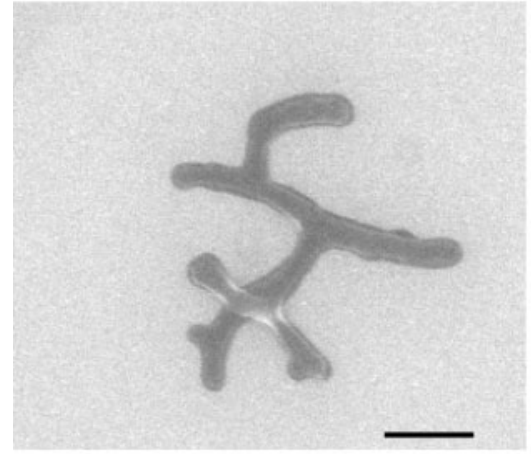

(g) +MinCD

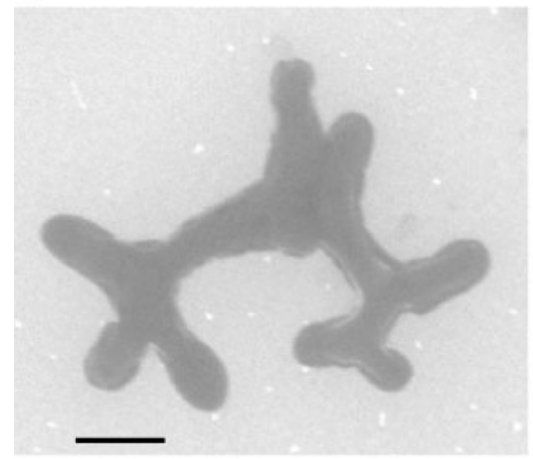

(j) +MinCDE

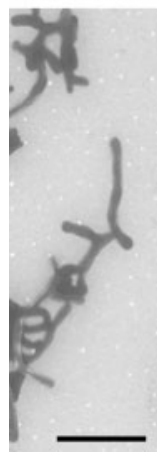

(b) +GusA

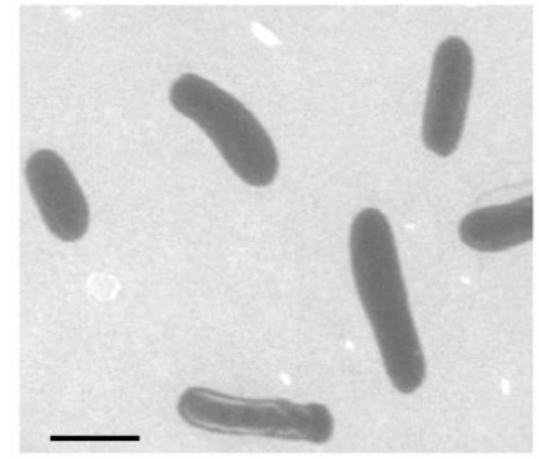

(e) $+\operatorname{Min} D$

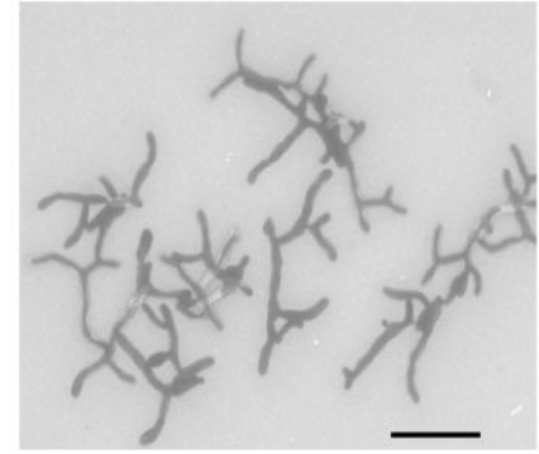

(h) +MinCD

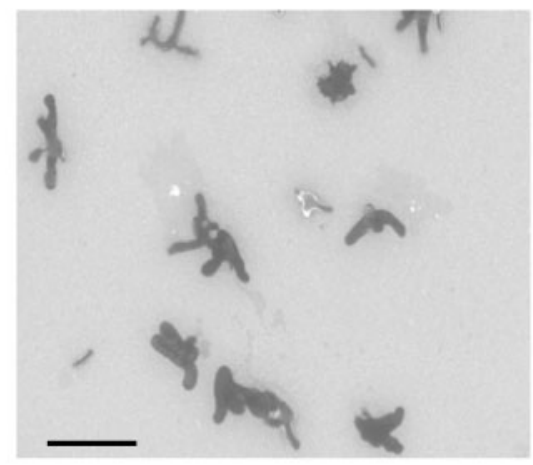

(k) + MinDE

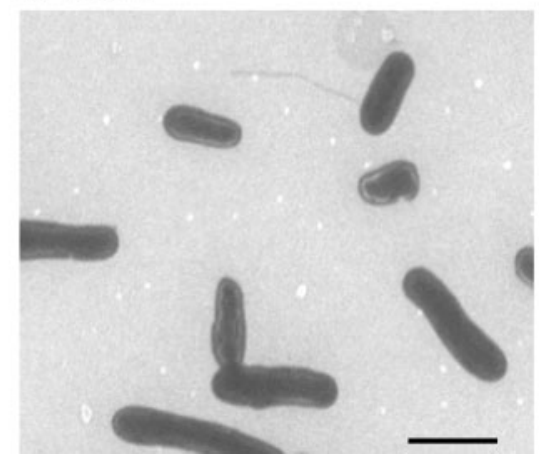

(c) + MinC

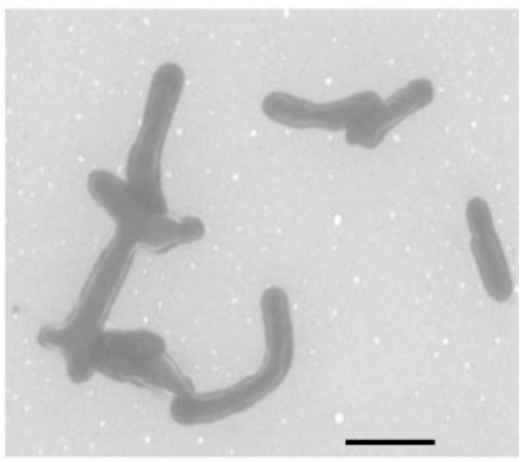

(f) + MinE

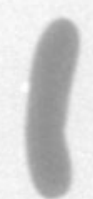

(i) +MinCDE

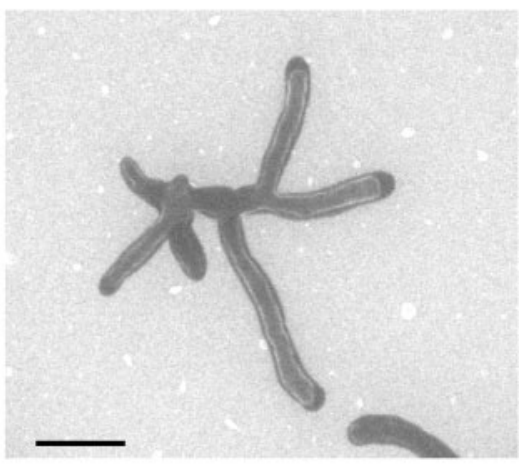

(I) $+\operatorname{MinDE}$

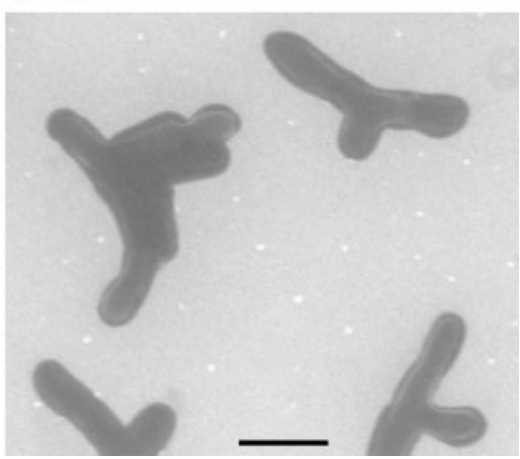

Fig. 4. The effect of min overexpression on the cell morphology of $S$. meliloti Rm1021. Environmental scanning electron micrographs of $\operatorname{Rm} 1021$ (a) overexpressing gusA (b), $\min C(\mathrm{c}), \min D(\mathrm{~d}, \mathrm{e}), \min E(\mathrm{f}), \min C D(\mathrm{~g}, \mathrm{~h}), \min C D E(\mathrm{i}, \mathrm{j})$ and $\min D E$ $(k, l)$. Cells were grown in LBmc medium and then induced by IPTG as described in Methods. Bars, $1 \mu$ M (a, b, c, d, f, g, i, k, l), $5 \mu \mathrm{m}(e, h, j)$. 
(a) +GusA

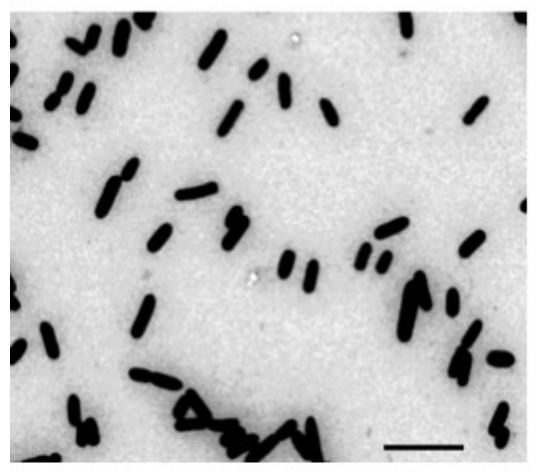

(d) + MinE

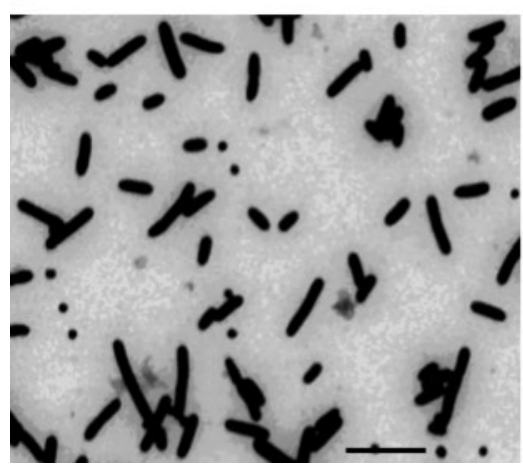

(b) $+\mathrm{MinC}$

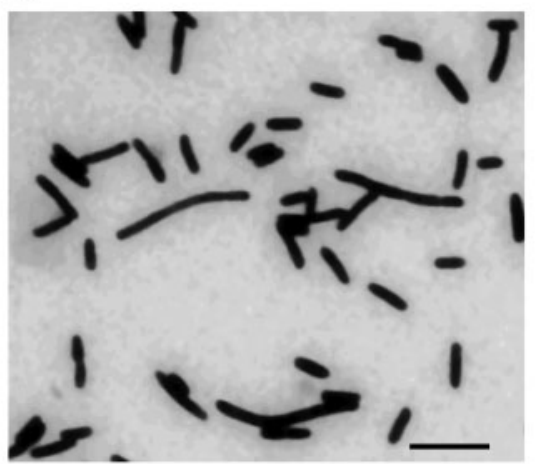

(e) $+\operatorname{MinCD}$

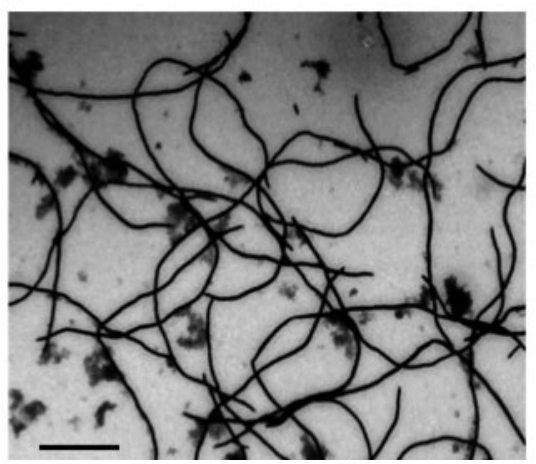

(c) $+\operatorname{Min} D$

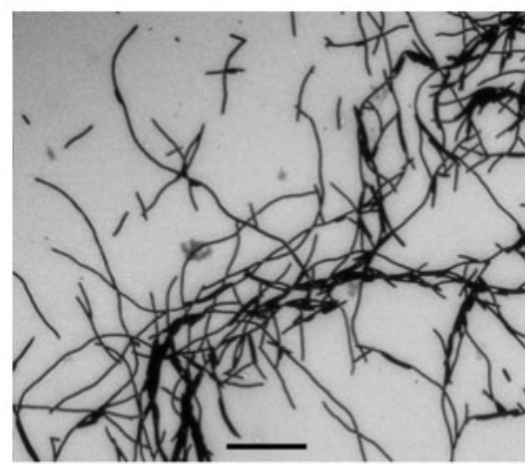

(f) $+\operatorname{MinCDE}$

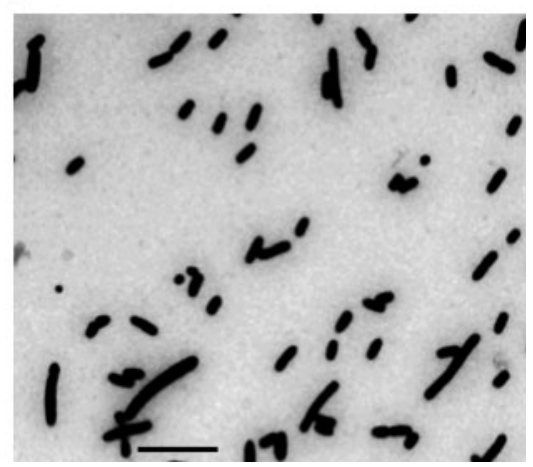

Fig. 5. Effect of overexpressed S. meliloti Min proteins on the morphology of $E$. coli $\mathrm{DH} 5 \alpha$. Environmental scanning electron micrographs of $E$. coli $\mathrm{DH} 5 \alpha(\mathrm{a})$ overexpressing $\min C(\mathrm{~b}), \min D(\mathrm{c}), \min E(\mathrm{~d}), \min C D(\mathrm{e})$ and $\min C D E$ (f). Cells were grown in LB medium and then induced with $0.1 \mathrm{mM}$ IPTG as described in Methods. Bars, $4 \mu \mathrm{m}(\mathrm{a}, \mathrm{b}, \mathrm{d}, \mathrm{f}), 20 \mu \mathrm{m}(\mathrm{c}, \mathrm{e})$.

minicells of Synechocystis are able to further divide, but those of $E$. coli and B. subtilis are anucleate. The $\min C$ and $\min D$ mutants of Neisseria gonorrhoeae do not show a minicell phenotype, but rather a gross enlargement of their round shape, causing cell lysis (Ramirez-Arcos et al., 2001; Szeto et al., 2001). Thus while the Min system is required for proper septum location in a wide range of bacteria, the phenotypes resulting from min gene mutations can be very different.

Both the free-living and nodule phenotypes of the $\triangle \min C D E$ mutant demonstrate that in the absence of the Min proteins, other systems in S. meliloti may direct appropriate cell septation. Mutations in such systems may be lethal in the min mutant background, as in the case of the $\operatorname{sim} A$ mutants of E. coli (Bernhardt \& de Boer, 2005). Many bacterial species lack Min homologues (Caulobacter crescentus, Haemophilus influenzae and Staphylococcus aureus) and thus must have other mechanisms to replace the role of the MinCDE proteins in determining Z-ring assembly (Margolin, 2003; Figge et al., 2003). In this respect, we note that the megaplasmid location of the min genes in $S$. melilot $i$ is consistent with a dispensable function. Moreover, the minCDE genes are located on the p42e plasmid of Rhizobium etli (Gonzalez et al., 2006) and the pRL11 plasmid in Rhizobium leguminosarum (Young et al., 2006).
Six of the nine genes required for cytokinesis in E. coli [ftsA, $f t s I, f t s K(2), f t s Q, f t s W$ and $f t s Z(2)]$ have been annotated in the S. meliloti genome (Galibert et al., 2001). Recent transcriptome analysis of $S$. meliloti shows that the expression of these genes is down-regulated in bacteroids (Barnett et al., 2004). Our mutant data show that while $\min C D E$ genes are not absolutely required for the bacteroid differentiation process, the $\min$ genes are expressed in nodules. Both the free-living and nodule phenotypes of the $\triangle \min C D E$ mutant demonstrate that there is redundancy in the pathway(s) determining septa formation in S. meliloti.

The cellular concentrations of MinCDE proteins are maintained within certain levels to avoid disrupting cell division, as overexpression of $S$. meliloti min genes in wildtype or disruption of the minE gene resulted in aberrant morphology and growth. We identified a promoter upstream of the $\min C$ gene and identified two putative CtrA-binding sites (Fig. 2c). S. meliloti CtrA is essential and binds to the five CtrA-binding sites in the ctrA promoter region (Barnett et al., 2001). CtrA is a DNA-binding response regulator and regulates expression of about 100 genes involved in cell cycle progression and morphogenesis in Caulobacter crescentus (Laub et al., 2000). The presence of CtrA-binding sites upstream of the $\min C$ gene indicates that 
CtrA may be involved in regulating $\min C D E$ expression, as implied for Brucella abortus minC expression (Bellefontaine et al., 2002; Hallez et al., 2004).

The complex cell morphological changes resulting from a minE mutation or overproduction of Min proteins are similar to those in S. meliloti overexpressing CcrM (Wright et al., 1997), DnaA (Sibley et al., 2006) and FtsZ (Latch \& Margolin, 1997), or treatment with DNA-damaging agents (Latch \& Margolin, 1997). This phenotype is correlated with blocked cell division (Latch \& Margolin, 1997; Wright et al., 1997; Sibley et al., 2006) and loss of normal control of DNA replication initiation (Wright et al., 1997). It remains to be established whether a blockage in cell division always leads to branching in S. meliloti; however, this possibility is of considerable interest given the cellular morphology of $\mathrm{N}_{2^{-}}$ fixing bacteroids. We do not exclude the possibility that the MinCDE proteins may be involved in other cell process such as genome partitioning and segregation, as in E. coli (Åkerlund et al., 2002).

\section{ACKNOWLEDGEMENTS}

We are grateful to Dr Valerie Oke and Dr Wayne G. Reeve for kindly providing us with plasmids. We are grateful to Alison Cowie for comments on this manuscript. This work was supported by funding from Genome Canada through the Ontario Genomics Institute, by funding from the Ontario Research and Development Challenge Fund, and with funding from NSERC.

\section{REFERENCES}

Åkerlund, T., Gullbrand, B. \& Nordström, K. (2002). Effects of the Min system on nucleoid segregation in Escherichia coli. Microbiology 148, 3213-3222.

Barnett, M. J., Hung, D. Y., Reisenauer, A., Shapiro, L. \& Long, S. R. (2001). A homolog of the CtrA cell cycle regulator is present and essential in Sinorhizobium meliloti. J Bacteriol 183, 3204-3210.

Barnett, M. J., Toman, C. J., Fisher, R. F. \& Long, S. R. (2004). A dual-genome symbiosis chip for coordinate study of signal exchange and development in a prokaryote-host interaction. Proc Natl Acad Sci U S A 101, 16636-16641.

Bellefontaine, A. F., Pierreux, C. E., Mertens, P., Vandenhaute, J., Letesson, J. J. \& Bolle, X. D. (2002). Plasticity of a transcriptional regulation network among alpha-proteobacteria is supported by the identification of CtrA targets in Brucella abortus. Mol Microbiol 43, 945-960.

Bernhardt, T. G. \& de Boer, P. A. J. (2005). SlmA, a nucleoidassociated, FtsZ binding protein required for blocking septal ring assembly over chromosomes in E. coli. Mol Cell 18, 555-564.

Bernstein, J. A., Khodursky, A. B., Lin, P. H., Lin-Chao, S. \& Cohen, S. N. (2002). Global analysis of mRNA decay and abundance in Escherichia coli at single gene resolution using two-color fluorescent DNA microarrays. Proc Natl Acad Sci U S A 99, 9697-9702.

Bi, E. \& Lutkenhaus, J. (1991). FtsZ ring structure associated with division in Escherichia coli. Nature 354, 161-164.

Cha, J. H. \& Stewart, G. C. (1997). The $\operatorname{divIVA}$ minicell locus of Bacillus subtilis. J Bacteriol 179, 1671-1683.

Cowie, A., Cheng, J., Sibley, C. D., Fong, Y., Zaheer, R., Patten, C. L., Morton, R. M., Golding, G. B. \& Finan, T. M. (2006). An integrated approach to functional genomics: construction of a novel reporter gene fusion library for Sinorhizobium meliloti. Appl Environ Microbiol 72, 7156-7167.

de Boer, P. A., Crossley, R. E. \& Rothfield, L. I. (1989). A division inhibitor and a topological specificity factor coded for by the minicell locus determine proper placement of the division septum in E. coli. Cell 56, 641-649.

Edwards, D. H. \& Errington, J. (1997). The Bacillus subtilis DivIVA protein targets to the division septum and controls the site specificity of cell division. Mol Microbiol 24, 905-915.

Errington, J., Daniel, R. A. \& Scheffers, D. J. (2003). Cytokinesis in bacteria. Microbiol Mol Biol Rev 67, 52-65.

Figge, R. M., Easter, J. \& Gober, J. W. (2003). Productive interaction between the chromosome partitioning proteins, ParA and ParB, is required for the progression of the cell cycle in Caulobacter crescentus. Mol Microbiol 47, 1225-1237.

Finan, T. M., Hartwieg, E., Lemieux, K., Bergman, K., Walker, G. C. \& Signer, E. R. (1984). General transduction in Rhizobium meliloti. $J$ Bacteriol 159, 120-124.

Finan, T. M., Kunkel, B., Devos, G. F. \& Signer, E. R. (1986). Second symbiotic megaplasmid in Rhizobium meliloti carrying exopolysaccharide and thiamine synthesis genes. J Bacteriol 167, 66-72.

Finan, T. M., Weidner, S., Wong, K., Buhrmester, J., Chain, P., Vorholter, F. J., Hernandez-Lucas, I., Becker, A., Cowie, A. \& other authors (2001). The complete sequence of the 1,683-kb pSymB megaplasmid from the $\mathrm{N}_{2}$-fixing endosymbiont Sinorhizobium meliloti. Proc Natl Acad Sci U S A 98, 9889-9894.

Galibert, F., Finan, T. M., Long, S. R., Puhler, A., Abola, P., Ampe, F., Barloy-Hubler, F., Barnett, M. J., Becker, A. \& Boistard, P. (2001). The composite genome of the legume symbiont Sinorhizobium meliloti. Science 293, 668-672.

Gonzalez, V., Santamaria, R. I., Bustos, P., Hernandez-Gonzalez, I., Medrano-Soto, A., Moreno-Hagelsieb, G., Janga, S. C., Ramirez, M. A., Jimenez-Jacinto, V. \& other authors (2006). The partitioned Rhizobium etli genome: genetic and metabolic redundancy in seven interacting replicons. Proc Natl Acad Sci U S A 103, 3834-3839.

Hale, C. A., Meinhardt, H. \& de Boer, P. A. (2001). Dynamic localization cycle of the cell division regulator MinE in Escherichia coli. EMBO J 20, 1563-1572.

Hallez, R., Bellefontaine, A. F., Letesson, J. J. \& De Bolle, X. (2004). Morphological and functional asymmetry in alpha-proteobacteria. Trends Microbiol 12, 361-365.

Labes, M., Rastogi, V., Watson, R. \& Finan, T. M. (1993). Symbiotic nitrogen fixation by a nifA deletion mutant of Rhizobium meliloti: the role of an unusual ntrC allele. J Bacteriol 175, 2662-2673.

Latch, J. N. \& Margolin, W. (1997). Generation of buds, swellings, and branches instead of filaments after blocking the cell cycle of Rhizobium meliloti. J Bacteriol 179, 2373-2381.

Laub, M. T., McAdams, H. H., Feldblyum, T., Fraser, C. M. \& Shapiro, L. (2000). Global analysis of the genetic network controlling a bacterial cell cycle. Science 290, 2144-2148.

MacLellan, S. R., MacLean, A. M. \& Finan, T. M. (2006). Promoter prediction in the rhizobia. Microbiology 152, 1751-1763.

Margolin, W. (2003). Bacterial shape: growing off this mortal coil. Curr Biol 13, R705-R707.

Marston, A. L. \& Errington, J. (1999). Selection of the midcell division site in Bacillus subtilis through MinD-dependent polar localization and activation of MinC. Mol Microbiol 33, 84-96.

Mazouni, K., Domain, F., Cassier-Chauvat, C. \& Chauvat, F. (2004). Molecular analysis of the key cytokinetic components of cyanobacteria: FtsZ, ZipN and MinCDE. Mol Microbiol 52, 1145-1158. 
Mergaert, P., Uchiumi, T., Alunni, B., Evanno, G., Cheron, A., Catrice, O., Mausset, A. E., Barloy-Hubler, F., Galibert, F. \& other authors (2006). Eukaryotic control on bacterial cell cycle and differentiation in the Rhizobium-legume symbiosis. Proc Natl Acad Sci U S A 103, 5230-5235.

Miller, J. H. (1972). Experiments in Molecular Genetics. Cold Spring Harbor, NY: Cold Spring Harbor Laboratory.

Mohl, D. A., Easter, J., Jr \& Gober, J. W. (2001). The chromosome partitioning protein, $\mathrm{ParB}$, is required for cytokinesis in Caulobacter crescentus. Mol Microbiol 42, 741-755.

Oke, V. \& Long, S. R. (1999). Bacteroid formation in the Rhizobiumlegume symbiosis. Curr Opin Microbiol 2, 641-646.

Østerås, M., Stanley, J. \& Finan, T. M. (1995). Identification of Rhizobium-specific intergenic mosaic elements within an essential two-component regulatory system of Rhizobium species. J Bacteriol 177, 5485-5494.

Paau, A. S., Lee, D. \& Cowles, J. R. (1977). Comparison of nucleic acid content in populations of free-living and symbiotic Rhizobium meliloti by flow microfluorometry. J Bacteriol 129, 1156-1158.

Prentki, P. \& Krisch, H. M. (1984). In vitro insertional mutagenesis with a selectable DNA fragment. Gene 29, 303-313.

Quandt, J. \& Hynes, M. F. (1993). Versatile suicide vectors which allow direct selection for gene replacement in gram-negative bacteria. Gene 127, 15-21.

Ramirez-Arcos, S., Szeto, J., Beveridge, T. J., Victor, C., Francis, F. \& Dillon, J.-A. R. (2001). Deletion of the cell-division inhibitor MinC results in lysis of Neisseria gonorrhoeae. Microbiology 147, 225-237.

Reeve, W. G., Tiwari, R. P., Worsley, P. S., Dilworth, M. J., Glenn, A. R. \& Howieson, J. G. (1999). Constructs for insertional mutagenesis, transcriptional signal localization and gene regulation studies in root nodule and other bacteria. Microbiology 145, 1307-1316.

Sambrook, J. \& Russell, R. W. (2001). Molecular Cloning: a Laboratory Manual, 3rd edn. Cold Spring Harbor, NY: Cold Spring Harbor Laboratory.

Schweizer, H. P., Klassen, T. R. \& Hoang, T. (1996). Improved methods for gene analysis and expression in Pseudomonas. In Biology of Pseudomonas, pp. 229-237. Edited by T. Nakazawa, K. Furukawa,
D. Haas \& S. Silver. Washington, DC: American Society for Microbiology.

Shih, Y. L., Le, T. \& Rothfield, L. (2003). Division site selection in Escherichia coli involves dynamic redistribution of Min proteins within coiled structures that extend between the two cell poles. Proc Natl Acad Sci U S A 100, 7865-7870.

Sibley, C. D., Maclellan, S. R. \& Finan, T. (2006). The Sinorhizobium meliloti chromosomal origin of replication. Microbiology 152, 443-455.

Soupene, E., Foussard, M., Boistard, P., Truchet, G. \& Batut, J. (1995). Oxygen as a key developmental regulator of Rhizobium meliloti $\mathrm{N}_{2}$-fixation gene expression within the alfalfa root nodule. Proc Natl Acad Sci U S A 92, 3759-3763.

Spurr, A. R. (1969). A low-viscosity epoxy resin embedding medium for electron microscopy. J Ultrastrut Res 26, 31-43.

Szeto, J., Ramirez-Arcos, S., Raymond, C., Hicks, L. D., Kay, C. M. \& Dillon, J. A. R. (2001). Gonococcal MinD affects cell division in Neisseria gonorrhoeae and Escherichia coli and exhibits a novel selfinteraction. J Bacteriol 183, 6253-6264.

Vasse, J., Debilly, F., Camut, S. \& Truchet, G. (1990). Correlation between ultrastructural differentiation of bacteroids and nitrogen fixation in alfalfa nodules. J Bacteriol 172, 4295-4306.

Watson, R. J., Heys, R., Martin, T. \& Savard, M. (2001). Sinorhizobium meliloti cells require biotin and either cobalt or methionine for growth. Appl Environ Microbiol 67, 3767-3770.

Wright, R., Stephens, C. \& Shapiro, L. (1997). The CcrM DNA methyltransferase is widespread in the alpha subdivision of proteobacteria, and its essential functions are conserved in Rhizobium meliloti and Caulobacter crescentus. J Bacteriol 179, 5869-5877.

Young, J. P., Crossman, L. C., Johnston, A. W., Thomson, N. R., Ghazoui, Z. F., Hull, K. H., Wexler, M., Curson, A. R., Todd, J. D. \& other authors (2006). The genome of Rhizobium leguminosarum has recognizable core and accessory components. Genome Biol 7, R34.

Yuan, Z. C., Zaheer, R. \& Finan, T. M. (2006). Regulation and properties of PstSCAB, a high-affinity, high-velocity phosphate transport system of Sinorhizobium meliloti. J Bacteriol 188, 1089-1102.

Edited by: C. W. Ronson 